\title{
KAJIAN EKSPERIMENTAL PELUNCURAN KAPAL MENGGUNAKAN AIR BAG
}

\section{EXPERIMENTAL STUDY ON SHIP LAUNCHING USING AIRBAGS}

\author{
Zulis Irawanto ${ }^{a}$, Navik Puryantini ${ }^{a}$, Baharudin Ali $^{a}$, Budi Setyo Prasodjo ${ }^{b}$ \\ a Balai Teknologi Hidrodinamika \\ Deputi Teknologi Industri Rancang Bangun dan Rekayasa - BPPT \\ JI. Hidrodinamika - Kampus ITS Sukolilo, Surabaya - 60112 \\ Telp. 031-5948060, Fax. 031-59480600 \\ E-mail : baharudin.ali@bppt.go.id, zulis.irawanto@bppt.go.id, navik.puryantini@bppt.go.id
}

\author{
b INPEX CORPORATION \\ Floor TCC Batavia Tower One Lantai 37 \\ Jl. KH Mas Masyur Kav 126 Jakarta Pusat \\ Telp. 02129700100 \\ E-mail: budi.prasodjo@inpex.co.jp
}

\begin{abstract}
Abstrak
Makalah ini melaporkan hasil penelitian di Balai Teknologi Hidrodinamika yang mengkaji peluncuran kapal dengan menggunakan air bag. Metode yang digunakan adalah uji model dengan melakukan studi sensitivitas beberapa parameter yang berpengaruh pada peluncuran kapal. Analisis dilakukan pada beberapa kondisi ekstrim yaitu kondisi terjadinya benturan, kondisi pada sudut pitch maksimum, dan kondisi pada freeboard minimum. Melalui uji model, dapat diketahui perilaku gerakan kapal saat diluncurkan dengan menggunakan air bag, serta dapat diketahui tingkat keselamatan peluncuran kapal.
\end{abstract}

Kata kunci: Peluncuran kapal, Air bag, Uji model

\begin{abstract}
This paper reports a research in Laboratory for Hydrodynamics Technology that studies ship launching using air bags. The methodology used was model test and sensitivity analysis on parameters influencing ship launching. The Analysis was carried out on the following extreme conditions: collision condition, condition of maximum pitch angle, and condition of minimum freeboard. From the model test, the behaviour of ship motion during launching can be measured, and the safety of the launching can be predicted.
\end{abstract}

Key Words: ship launching, air bag, model test

Diterima (received ) : 14 Desember 2018 , Direvisi (revised ) : 01 Maret 2019

Disetujui (accepted) : 25 Maret 2019

\section{PENDAHULUAN}

Dalam sistem produksi galangan, peluncuran merupakan proses yang sangat penting karena tahap peluncuran adalah proses yang memakan waktu dan juga biaya tinggi ${ }^{1)}$. Proses peluncuran bangunan apung pada umumnya dilakukan dengan sistem launching (end launching dan side (aunching)2. Pada end launching bagian belakang bangunan apung/ kapal akan menghadap ke air, sehingga akan menyentuh air lebih dahulu selama proses peluncuran dengan pertimbangan bahwa bentuk bagian belakang kapal mempunyai gaya apung dan drag force yang lebih besar 
dibanding bagian depan. Untuk galangan menengah dan besar pada proses peluncuran kapal menggunakan fasilitas floating dock, dimana setelah kapal selesai dibangun floating dock dibenamkan sampai kedalaman tertentu sampai kapal bisa terapung dengan sendirinya kemudian kapal ditarik keluar dari floating dock. Sedangkan pada graving dock, dimana bagian depan graving dock yang berhadapan dengan air memiliki pintu kedap air sehingga dalam peluncuran kapalnya air dipompa masuk kedalam graving dock sampai kapal bisa terapung dengan sendirinya, kemudian pintu kedap dibuka dan kapal ditarik ke luar dari graving dock.

Dari ketiga cara peluncuran di atas diperlukan investasi yang tidak murah untuk membangun struktur sepatu luncur / cradle pada kasus peluncuran end dan side launching apalagi jika menggunakan floating dock dan graving dock, akan dibutuhkan investasi yang sangat mahal. Dari keterbatasan ini muncul teknologi inovasi yang praktis dan ekonomis untuk peluncuran kapal yang fleksibel, aman, dapat dipercaya, tidak banyak aset tertanam, tidak banyak perawatan, yaitu menggunakan air bag ${ }^{3)}$.

Sampai saat ini penelitian tentang peluncuran kapal menggunakan air bag masih kurang, sehingga informasi ilmiah tentang hal tersebut sangat minim. Beberapa kendala yang ada dalam praktek lapangan antara lain kesulitan memprediksi perilaku kapal saat diluncurkan dengan air bag, kesulitan menginvestigasi kondisi-kondisi kritis peluncuran kapal serta belum tersedia petunjuk operasional keselamatannya.

Kelebihan penggunaan air bag berdasarkan hasil penelitian menyimpulkan bahwa didapat penurunan jam orang sekitar $41 \%$ dibandingkan slipway. Sedangkan biaya investasi lebih rendah 37\% dibandingkan slipway. Dari hasil analisis jam orang, didapatkan hasil peningkatan produktivitas yang terjadi sebesar $69 \%$ dalam penggunaan air bag untuk kegiatan docking dan undocking ${ }^{4)}$.

Meskipun demikian, peluncuran kapal dengan menggunakan air bag mempunyai potensi resiko yang besar pada kerusakan kapal akibat kegagalan peluncuran kapal(5). Salah satu contoh kegagalan peluncuran kapal dengan menggunakan air bag adalah meletusnya air bag dan meluncurnya kapal tanpa kontrol sehingga membuat kapal yang diluncurkan terbalik ${ }^{6}$. Untuk mengurangi resiko kegagalan peluncuran tersebut diperlukan adanya perhitungan dan analisis ${ }^{7}$.

Peluncuran dengan menggunakan air bag ini masih perlu pembuktian dan analisa yang lebih dalam, terutama dalam hal keberhasilan dalam proses peluncuran dan keselamatan. Dengan mengganti struktur sepatu luncur yang menetap (fixed structure) ke air bag yang bergerak translasi dan rotasi (menggelinding), maka pergerakan air bag dan pergerakan dinamis bangunan laut yang diletakkan diatasnya akan lebih sulit untuk dikontrol. Banyak variabel dinamis yang perlu diketahui, dianalisa dan dipecahkan, sehingga proses peluncuran ini terbukti bisa dilaksanakan dengan sukses dan aman. Selama ini proses peluncuran dengan menggunakan air bag ini hanya didasarkan oleh pengalaman dan trial and error.

Analisa yang serius mengenai peluncuran menggunakan air bag menjadi sangat krusial terutama pada kondisi berikut:

- Kapal yang diluncurkan mempunyai rasio panjang dan lebar (L/B) yang kecil

- Kondisi landasan luncur dan kondisi perairan yang kurang ideal.

Kapal yang akan diluncurkan adalah struktur yang sangat mahal, sehingga pekerjaan peluncuran yang hanya berdasarkan pengalaman dan trial dan error harus diminimalkan, oleh karena itu analisa dan pengkajian yang lebih mendalam mengenai peluncuran kapal dengan menggunakan air bag mutlak harus dilakukan, sehingga resiko kegagalan juga bisa ditekan seminim mungkin.

Sebuah metode analisis tentang peluncuran kapal menggunakan air bag dilakukan oleh Volenyuk ${ }^{8}$ yang menyajikan perhitungan dan diagram peluncuran, baik untuk peluncuran menggunakan air bag maupun peluncuran tradisional, serta analisis komparatif untuk kedua metode peluncuran tersebut. Analisis menunjukkan bahwa selama peluncuran menggunakan air bag, float off dimulai lebih awal dibandingkan pada peluncuran tradisional.

Pendekatan yang lebih dapat diandalkan untuk memprediksi kinerja peluncuran kapal diteliti oleh Fitriadhy9) dengan simulasi Computational Fluid Dynamic (CFD) untuk mendapatkan hasil yang lebih akurat. Beberapa parameter seperti sudut dan panjang landasan luncur telah diperhitungkan dalam simulasi yang ditujukan untuk memberikan gambaran tentang pengaruhnya pada kinerja peluncuran melintang, terutama terhadap waktu tipping kapal. Simulasi komputasi mengungkapkan bahwa meningkatkan sudut landasan luncur dan menurunkan rasio $d / L$ dapat menghasilkan waktu tipping yang lebih cepat.

Sebuah studi komparatif yang dilakukan Rudan ${ }^{10)}$ membandingkan berbagai metode 
analitis perhitungan peluncuran kapal yang dibandingkan dengan pengukuran DGPS dan kamera video. Hasil analisis menunjukkan adanya perbedaan hasil perhitungan yang cukup signifikan terutama untuk estimasi posisi berhenti kapal yang selain disebabkan perbedaan metode perhitungan juga disebabkan ketidakpastian berkaitan dengan tahanan air.

Pada metode analitis matematis, peluncuran kapal menggunakan air bag merupakan masalah yang sangat kompleks, serta terdapat beberapa fenomena yang sulit dirumuskan secara matematis. Adanya ketidakpastian pada hasil perhitungan analitis menjadi latar belakang diperlukannya uji model peluncuran kapal menggunakan air bag. Melalui uji model dapat diperoleh gambaran tentang perilaku gerakan kapal ketika meluncur bersama air bag. spesifikasi ukuran utama kapal sebagaimana ditunjukkan pada Tabel 1, dan lines plan pada Gambar 1.

Pengujian dilakukan dengan studi sensitivitas beberapa parameter yang berpengaruh pada peluncuran kapal. Uji model tersebut dianggap penting dalam rangka melengkapi kajian teknis sekaligus mengetahui fenomena gerakan kapal saat meluncur dengan air bag.

Tabel 1.

Ukuran utama kapal

\begin{tabular}{|c|c|}
\hline Uraian & Ukuran (m) \\
\hline Loa (m) & 89,78 \\
\hline Lpp (m) & 85,50 \\
\hline B (m) & 15,00 \\
\hline $\mathrm{H} \quad(\mathrm{m})$ & 7,00 \\
\hline $\mathrm{T} \quad$ (m) & 5,00 \\
\hline
\end{tabular}

\section{BAHAN DAN METODE}

Pada penelitian ini, kapal yang dipelajari adalah sejenis kapal tanker dengan
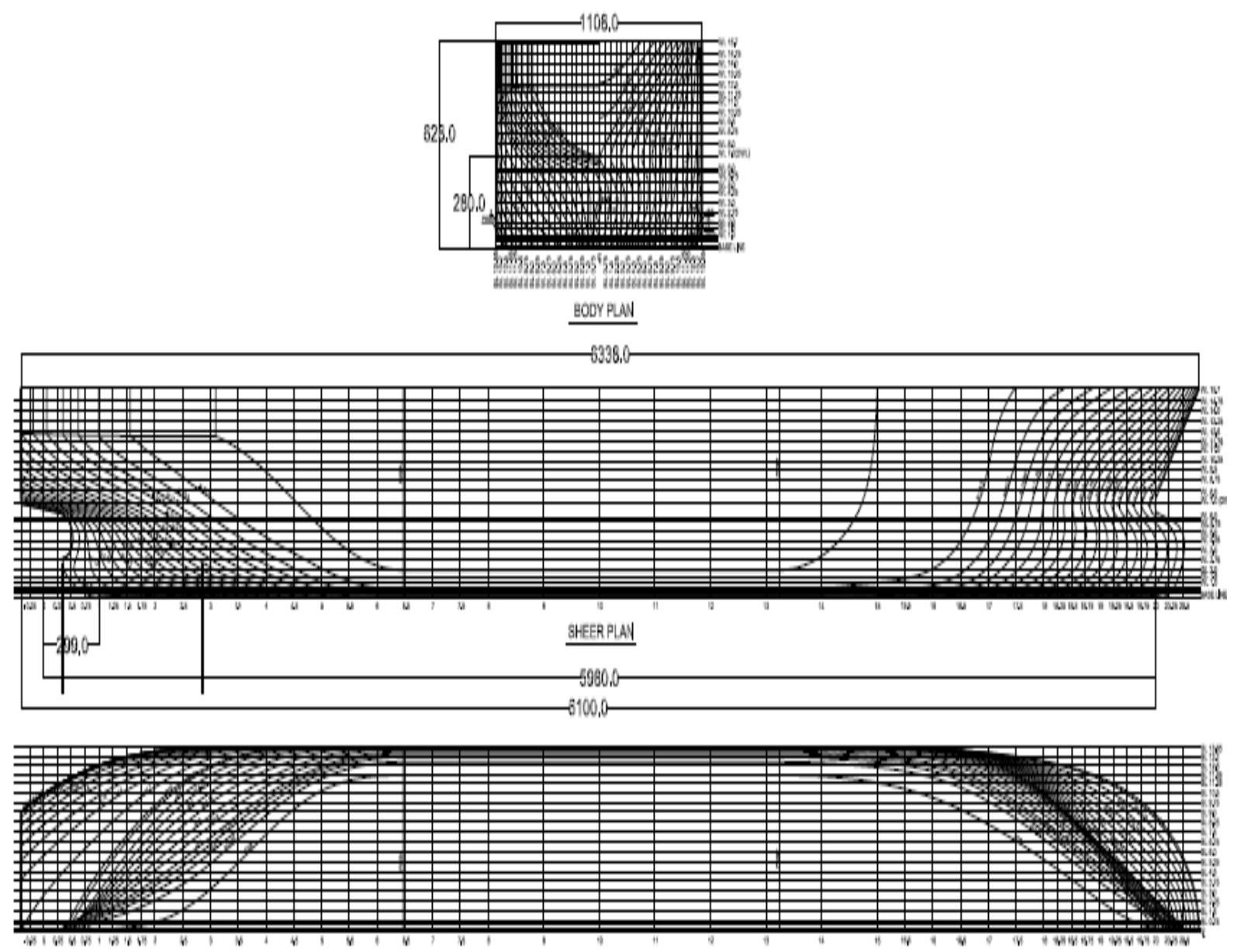

Gambar 1.

Lines plan kapal tanker 


\section{Pembuatan Model Kapal}

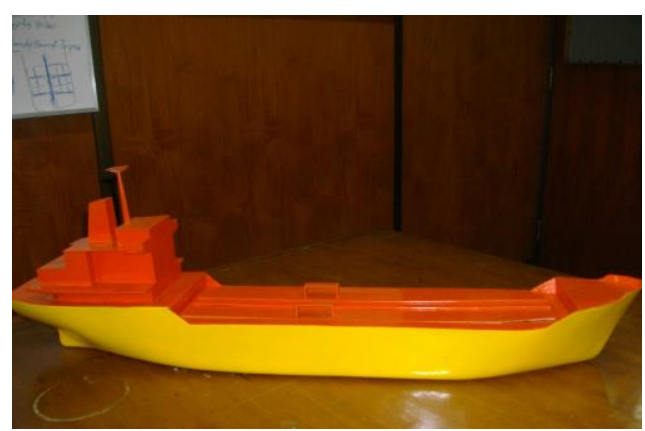

Gambar 2.

Model kapal Tanker

Untuk keperluan uji model kapal dilakukan pembuatan model uji yang merupakan representasi dari kapal yang akan diteliti. Model kapal dibuat dari bahan fiberglass dengan menggunakan skala 1:100 lihat Gambar 2.

\section{Pembuatan Model Air bag}

Bentuk dasar dari air bag adalah sebuah balon pneumatic yang berbentuk silinder (Gambar 3). Lapisan karet dari air bag ini dilapisi dengan penguat kawat sintetik seperti halnya ban mobil.

Lapisan karet bagian luar berfungsi melindungi lapisan kabel penguat dari abrasi dan gangguan eksternal lain. Senyawa ini memiliki kekuatan tarik dan sobekan yang cukup untuk menahan kondisi cuaca dan penggunaan ekstrim. Lapisan selanjutnya adalah lapisan sintetis dan kawat penguat, lapisan penguat ini terdiri dari kabel-ban sintetik yang umum dipakai pada ban karet modifikasi. Susunan kawat ini diatur pada sudut ideal untuk menahan tekanan internal dan mendistribusikan stressnya secara merata sehingga memberikan penguatan yang efisien. Pada bagian ujung air bag terdapat end fitting.

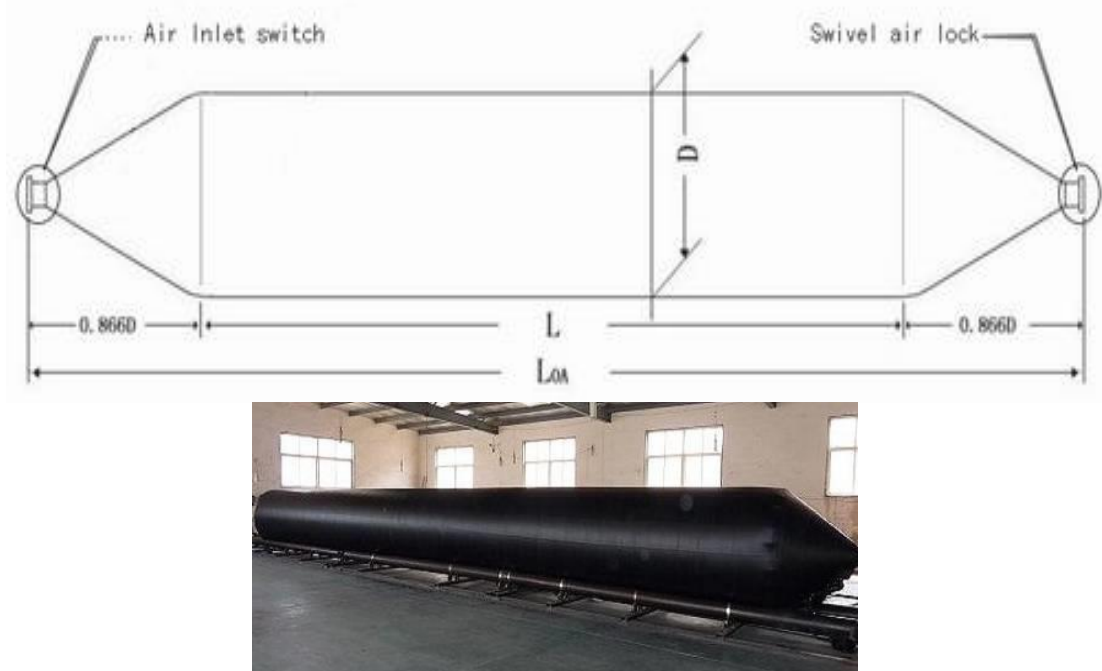

Gambar 3.

Air bag

\begin{abstract}
Standar spesifikasi air bag ship launching di pasaran:

Diameter (D)

$: 0,8-2 \mathrm{~m}$

Panjang efektif (EL) : : $6-18 \mathrm{~m}$

Panjang Total (TL) : : $7-19,5 \mathrm{~m}$

Spesifikasi lain dapat dibuat sesuai dengan permintaan klien. Pada penelitian ini, air bag model dibuat mengikuti skala model kapal (1 : 100). Dengan pembuatan secara manual model air bag berbahan plastik dan foam maka tekanan permukaan dan dimensi dapat dibuat sedemikian rupa sehingga menyerupai air bag.
\end{abstract}

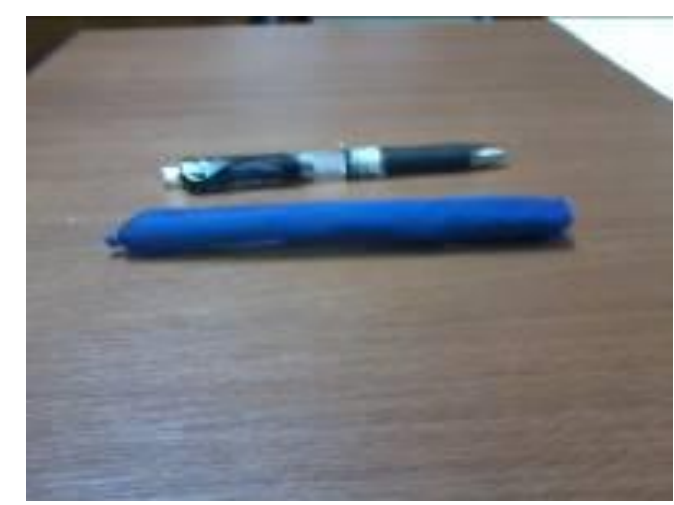

Gambar 4.

Air bag model 


\section{Metode Uji}

Pengujian peluncuran model dengan air bag yang dilakukan pada model kapal tanker dilakukan dengan berbagai variasi secara studi sensitivitas faktor yang berpengaruh pada peluncuran sehingga diketahui tingkat keselamatan pada peluncuran kapal serta mengetahui faktor yang berpengaruh pada peluncuran tersebut.

Untuk mengetahui tingkat keselamatan peluncuran kapal bisa diamati dari beberapa parameter berikut :

a. Terjadinya benturan dasar kapal, benturan pada bagian dasar kapal bisa terjadi karena peluncuran yang tidak direncanakan dengan baik. Benturan bisa terjadi antara bagian dasar kapal dengan landasan luncur atau dengan dasar air. Daerah yang berpeluang untuk terjadinya benturan adalah bagian ujung depan dan ujung belakang kapal. Di dalam uji model, terjadinya benturan bisa diamati secara visual atau dari evaluasi rekaman video.

b. Sudut pitch ( $\theta$ ) maksimum, di dalam peluncuran kapal menggunakan air bag, salah satu tahapan yang perlu dicermati adalah ketika titik berat kapal melewati air bag paling depan yang masih menumpu kapal. Pada tahap tersebut terjadi percepatan gerakan rotasi yang menyebabkan kapal bergerak menukik ke bawah (pitch). Semakin lama gerakan rotasi semakin cepat sampai akhirnya gerakan tersebut dilawan oleh gaya apung dan gaya dinamik sehingga kapal mencapai kondisi seimbang. Besarnya sudut pitch $(\theta)$ maksimum adalah salah satu parameter untuk mengetahui tingkat keselamatan peluncuran kapal. Semakin kecil sudut tersebut maka tingkat keselamatan peluncuran kapal adalah semakin baik.

c. Kedalaman maksimum dasar kapal (b) dan freeboard minimum (f), gerakan kapal meluncur merupakan kombinasi dari gerakan translasi vertikal dan horizontal serta gerakan rotasi. Kombinasi dari gerakan tersebut mengakibatkan ujung kapal menjadi bagian yang perlu mendapatkan perhatian keselamatannya. Dasar kapal pada bagian ujung merupakan salah satu bagian kapal yang berpeluang untuk terjadinya benturan dengan dasar air. Maka pengukuran kedalaman dasar kapal pada bagian ujung terhadap permukaan air (b) menjadi salah satu indikator tingkat keselamatan peluncuran kapal. Semakin kecil kedalaman (b) berarti tingkat keselamatan peluncuran adalah semakin baik

Selain bagian dasar kapal, geladak kapal di bagian ujung juga perlu di waspadai terutama apabila di bagian tersebut terdapat peralatan yang perlu dihindarkan dari air atau apabila di bagian tersebut banyak bukaan lubang yang memungkinkan air masuk ke lubang tersebut. Tingkat keselamatan untuk geladak ujung kapal bisa diukur dari jarak freeboard di daerah tersebut terhadap permukaan air (f). Semakin besar jarak tersebut mengindikasikan tingkat keselamatan yang lebih besar.

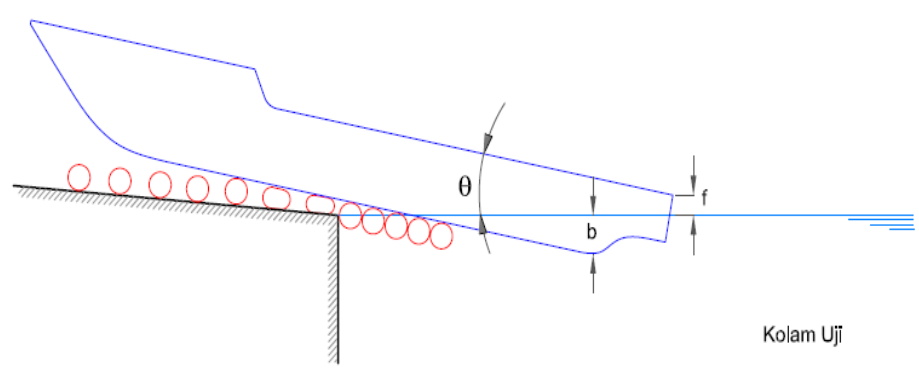

Gambar 5.

Skema kapal meluncur dengan air bag

Pada peluncuran kapal, kondisi pada nilai $b$ maksimum adalah identik dengan kondisi pada $f$ minimum. Oleh karena itu pada uji model dilakukan pengukuran pada 2 parameter saja yaitu sudut pitch maksimum ( $\theta$ ) dan freeboard minimum (f).

\section{Metode Analisa Data}

Analisis pada uji peluncuran model kapal dilakukan berdasarkan hasil rekaman video yang diambil dari arah samping model kapal. Analisis dilakukan pada setiap frame gambar dari data video untuk menentukan beberapa kondisi ekstrim berikut: 
a. Kondisi terjadinya benturan

b. Kondisi pada sudut pitch maksimum

c. Kondisi pada freeboard minimum

\section{Pengaruh sudut peluncuran}

Sudut peluncuran $(\alpha)$ yaitu sudut kemiringan landasan luncur terhadap bidang datar, merupakan salah satu faktor yang berpengaruh pada peluncuran kapal. Sudut kemiringan yang lebih besar bisa mengurangi gaya gesek dan memperbesar percepatan gerakan luncur pada kapal yang memudahkan kapal meluncur ke air. Namun kecepatan luncur yang tidak terkontrol dikhawatirkan bisa membahayakan keselamatan struktur bangunan kapal. Uji model merupakan salah satu metode untuk mengetahui keamanan peluncuran kapal.

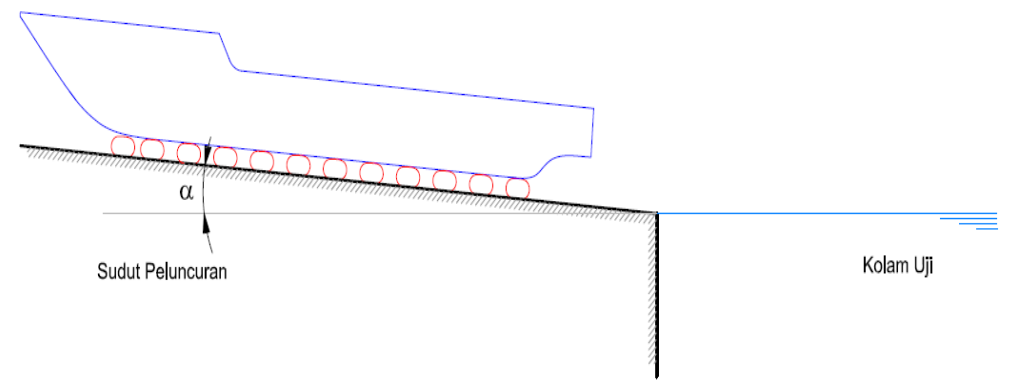

Gambar 6.

Skema sudut peluncuran kapal

\section{HASIL DAN PEMBAHASAN}

Uji peluncuran model kapal dengan arah mundur dilakukan pada beberapa variasi sudut kemiringan dan hasilnya ditampilkan pada Gambar 7 dan 8.

Penentuan besarnya sudut peluncuran berdasarkan pada ketentuan sudut minimum dari persyaratan agar kapal dapat meluncur dengan gaya beratnya sendiri'), yaitu :

$$
\text { Tg } \alpha>\text { fs; Tg } \alpha>0,04 ; \alpha>2,29
$$

Dari persyaratan tersebut diperoleh nilai sudut minimum $2,29^{\circ}$ sehingga untuk batas bawah sudut minimum diambil nilai $3^{\circ}$. Untuk nilai sudut terbesar menggunakan ketentuan

$$
\operatorname{Tga}=1 / 1,1 . \mathrm{B}(\text { lebar kapal) }
$$

Dari ketentuan tersebut, didapat nilai $5,01^{\circ}$ sehingga untuk sudut terbesar diambil nilai $5^{\circ}$.

Dari hasil uji model menunjukkan bahwa pengaruh sudut landasan luncur tidak terlalu berpengaruh secara signifikan pada gerakan luncur kapal. Pada beberapa variasi sudut tersebut gerakan luncur kapal menunjukkan pola gerakan yang hampir sama dan mempunyai sudut pitch maksimum yang hampir sama yaitu di sekitar nilai $6,2^{\circ}$ dan mencapai freeboard minimum di daerah buritan yang hampir sama pula yaitu di sekitar nilai $4,5 \mathrm{~m}$.

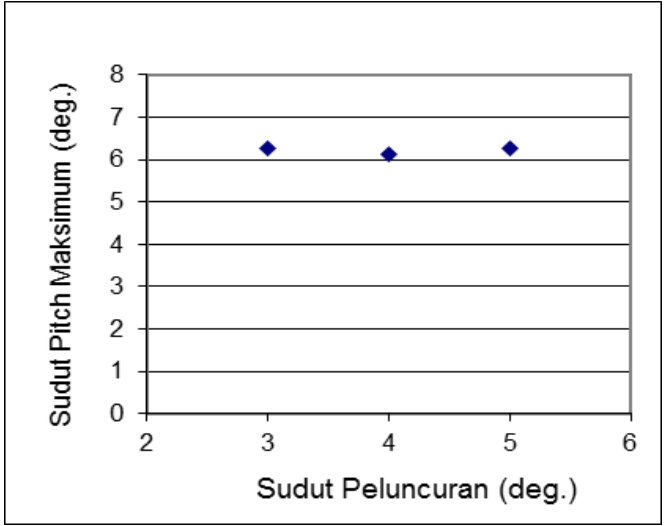

Gambar 7.

Sudut pitch maksimum pada beberapa sudut peluncuran

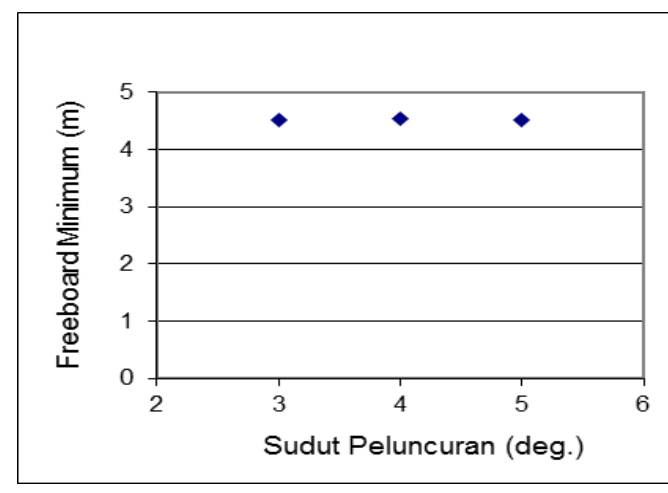

Gambar 8.

Freeboard minimum pada beberapa sudut peluncuran. 


\section{Pengaruh jarak memanjang kapal ke air}

Jarak kapal ke air merupakan salah satu faktor yang perlu dipertimbangkan pada peluncuran kapal. Pada gerakan meluncur bebas, semakin jauh benda bergerak maka kecepatan luncur akan semakin besar. Selain itu peluncuran yang dilakukan pada jarak yang berbeda menyebabkan awal mulainya gerakan rotasi (pitch) terjadi pada posisi yang berbeda pula. Pada jarak yang terlalu jauh dikhawatirkan ujung bawah kapal membentur landasan luncur sebelum kapal menyentuh air, atau ujung kapal membentur dasar air sebelum kapal mendapatkan gaya apung dan gaya hidrodinamik yang cukup untuk mengembalikan kapal ke posisi seimbang.

Pada uji model untuk peluncuran kapal menggunakan air bag dilakukan pada beberapa variasi jarak kapal terhadap air (x). Jarak kapal diukur dari ujung kapal ke tepi air

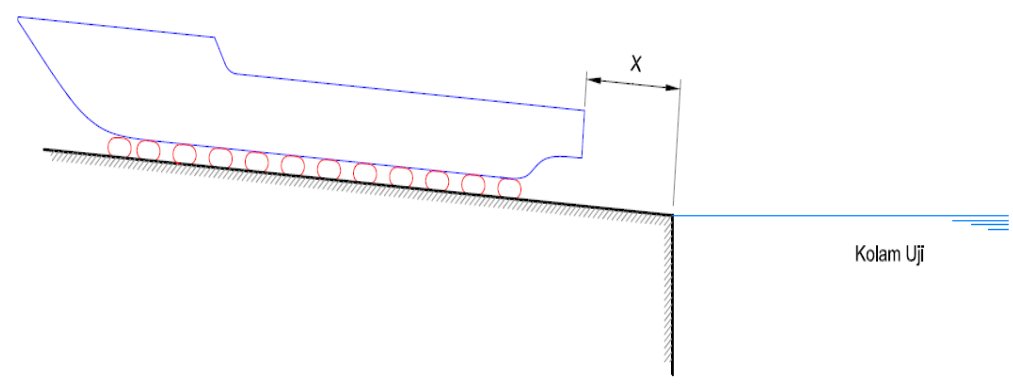

Gambar 8.

Skema jarak kapal ke air

Hasil uji peluncuran kapal dengan arah mundur pada beberapa variasi jarak kapal untuk model kapal tanker ditampilkan pada Gambar 9 dan 10.

Uji peluncuran pada beberapa variasi jarak kapal ke air untuk kapal tanker menunjukkan perbedaan nilai yang tidak terlalu signifikan untuk sudut pitch maksimum, sedangkan untuk freeboard minimum menunjukkan kecenderungan semakin berkurangnya freeboard minimum dengan semakin bertambahnya jarak kapal ke air.

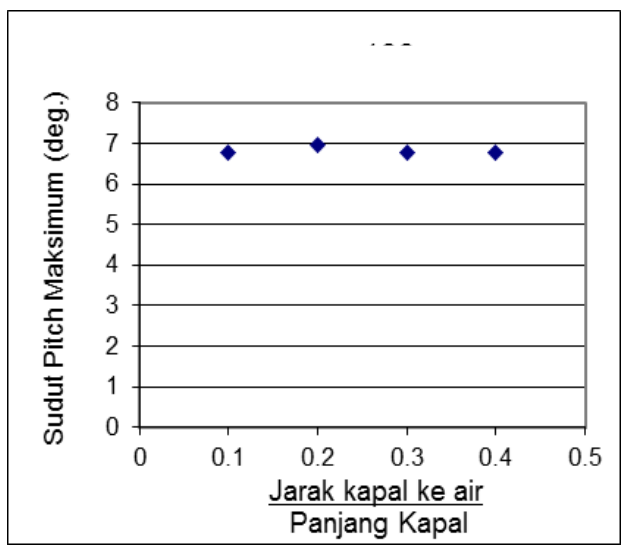

Gambar 9.

Sudut pitch maksimum pada beberapa variasi jarak peluncuran

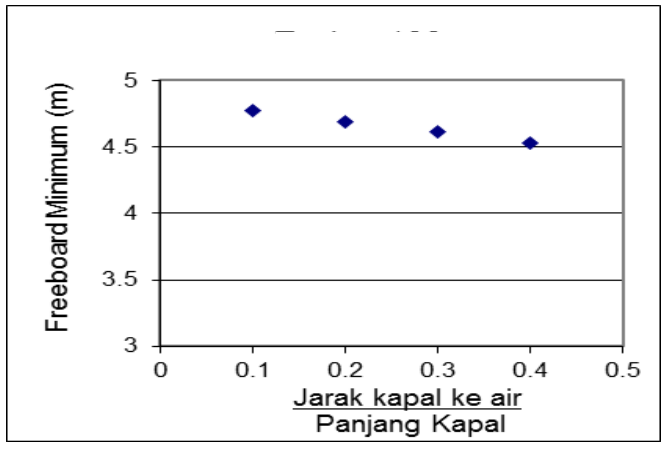

Gambar 10.

Freeboard minimum pada beberapa variasi jarak peluncuran

\section{Pengaruh posisi titik berat kapal (LCG)}

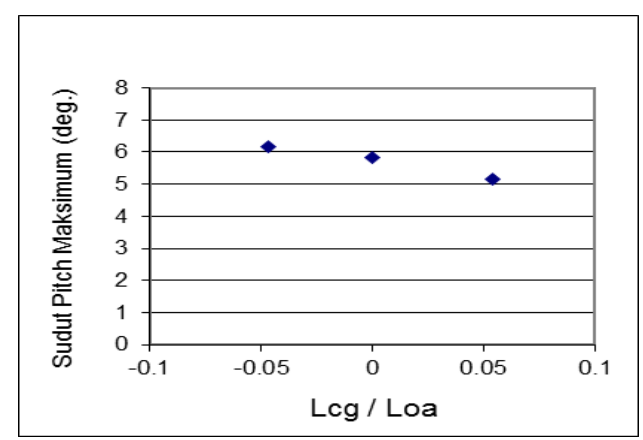

Gambar 11.

Sudut pitch maksimum pada beberapa variasi titik berat kapal 


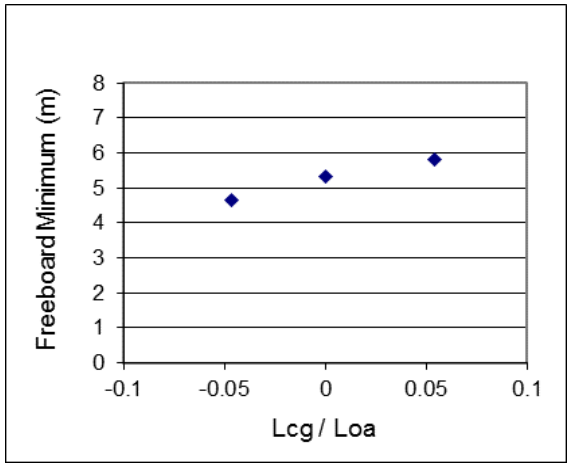

Gambar 12.

Freeboard minimum pada beberapa variasi titik berat kapal

Titik berat kapal diukur terhadap tengah kapal. Lcg positif ke arah depan kapal dan Lcg negatif ke arah belakang kapal. Pada uji peluncuran untuk mengetahui pengaruh posisi titik berat kapal dengan jalan menggeser pemberat ke arah depan atau ke belakang dari tengah kapal. Hasil uji peluncuran untuk kapal tanker ditampilkan pada Gambar 11 dan Gambar 12 .
Hasil uji peluncuran model kapal pada beberapa variasi titik berat kapal menunjukkan kecenderungan yang sama baik untuk kapal tanker. Semakin ke depan titik berat kapal atau semakin menjauhi air maka semakin kecil sudut pitch maksimum dan semakin besar freeboard minimum. Fenomena tersebut terjadi karena semakin dekat titik berat kapal ke arah air maka semakin cepat titik tersebut terlewati oleh air bag yang berada paling depan (yang paling dekat ke arah air). Dengan demikian gerakan rotasi kapal (pitch) terjadi lebih awal.

\section{Pengaruh tinggi ujung landasan luncur ke permukaan air}

Di dalam peluncuran kapal, kondisi landasan luncur tidak selamanya ideal. Ada kalanya ujung landasan tidak langsung menerus ke dalam air melainkan berubah secara bertahap mengikuti kontur kedalaman air atau bahkan bisa juga ujung landasan luncur terputus pada ketinggian tertentu di atas permukaan air seperti pada gambar 13.

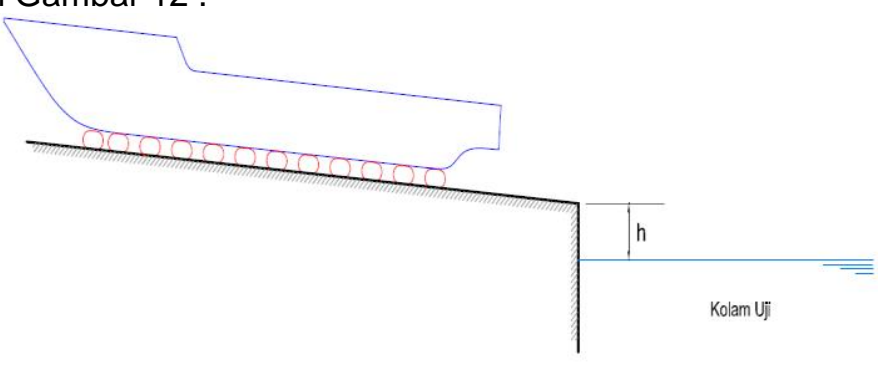

Gambar 13.

Skema tinggi landasan luncur ke air

Hasil uji peluncuran untuk kapal tanker dengan arah mundur pada beberapa variasi tinggi (h) ditampilkan pada Gambar 14 dan 15.

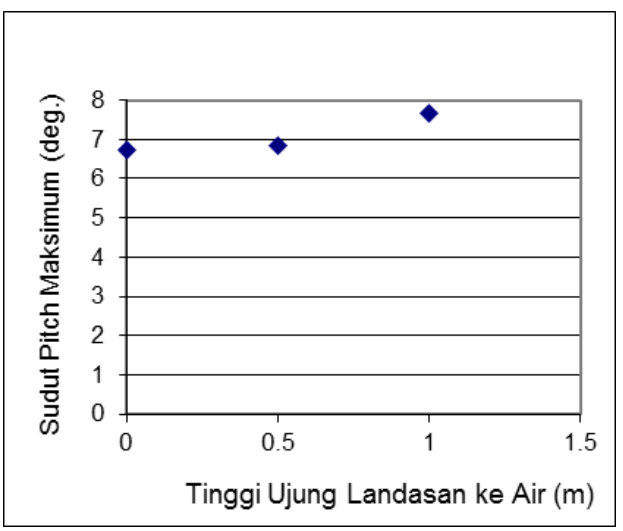

Gambar 14

Sudut pitch maksimum pada beberapa variasi tinggi landasan peluncuran

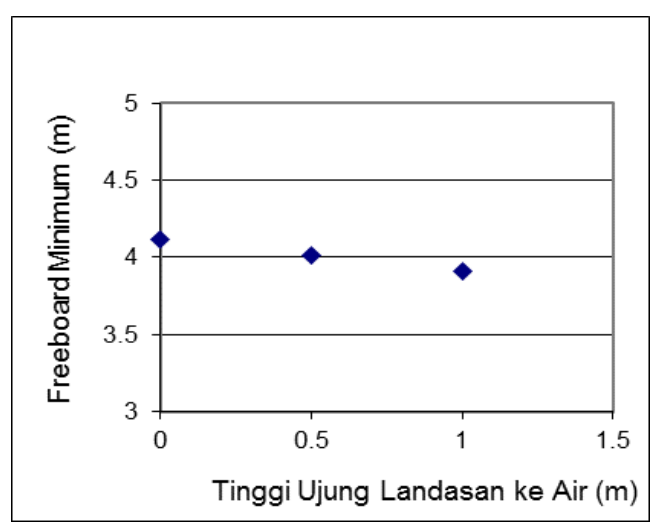

Gambar 15.

Freeboard minimum pada beberapa variasi tinggi landasan peluncuran 
Semakin tinggi jarak ujung landasan ke permukaan air menyebabkan sudut trim dan gerak rotasi kapal yang lebih besar sebelum kapal mendapatkan gaya perlawanan dari air. Selain itu ketika titik berat kapal melewati ujung landasan luncur maka muncul percepatan gerakan kapal dalam arah vertikal.

Seperti pada hasil percobaan di atas terlihat bahwa dengan semakin bertambahnya jarak ujung landasan luncur ke permukaan air menyebabkan sudut pitch maksimum yang lebih besar dan tinggi freeboard minimum yang semakin kecil.

\section{SIMPULAN}

Dari hasil uji peluncuran model kapal Tanker $100 \mathrm{~m}$ ini dapat disimpulkan bahwa uji model adalah metode yang tepat untuk mengetahui karakteristik gerakan meluncur kapal serta untuk mengetahui tingkat keselamatan peluncuran kapal. Sudut peluncuran tidak berpengaruh secara signifikan pada peluncuran kapal. Bertambahnya jarak memanjang kapal ke air menyebabkan berkurangnya freeboard minimum, tetapi tidak berpengaruh signifikan terhadap sudut pitch maksimum. Letak titik berat kapal (LCG) berpengaruh besar terhadap karakter gerakan meluncur kapal. Letak titik berat yang semakin menjauh dari air akan memperkecil sudut pitch maksimum dan memperbesar freeboard minimum. Kapal lebih aman diluncurkan pada landasan luncur yang menerus ke dalam air. Peluncuran kapal pada landasan luncur yang tidak menerus tetapi berhenti pada ketinggian tertentu terhadap permukaan air, semakin tinggi jarak tersebut semakin berbahaya bagi keselamatan kapal. Peluncuran kapal dalam arah mundur adalah lebih aman karena bentuk belakang kapal tumpul menyebabkan gaya hambatan air yang lebih besar untuk meredam gerakan kapal .

Hasil kajian tentang peluncuran kapal menggunakan airbag pada kapal tanker di atas bisa saja berbeda untuk tipe-tipe kapal yang lain Kajian yang lebih luas perlu dilakukan melalui uji model untuk berbagai tipe kapal yang lain.

\section{UCAPAN TERIMA KASIH}

Kementrian Riset, Teknologi dan Pendidikan Tinggi (Ristekdikti) yang telah mendanai penelitian ini melalui skema insentif Peningkatan Kemampuan Penelitian Perekyasa (PKPP) tahun anggaran 2012.

\section{DAFTAR PUSTAKA}

1. Ozkok, M., and Cebi, S., A fuzzy based assessment method for comparison of ship launching methods, Journal of Intelligent \& Fuzzy Systems, vol. 26, no. 2, p.781-791, 2014.

2. Rawson, K. J., and Tupper, E. C, Basic Ship Theory, Volume I Chapter 8, Fifth edition, Butterworth-Heinemann, 2001.

3. Qingdao Evergreen Maritime Co., Ltd, Evergreen Marine Air bags for Ship Launching and Landing, http://www.evergreen-

maritime.com/products/Ship-LaunchingAir bags-en3.html, diakses Desember 2018.

4. Haryani, A.O., dan Pribadi, T.W., Analisis Teknis dan Ekonomis Air bag System Untuk Meningkatkan Produktivitas Reparasi Kapal (Studi Kasus : PT. Adiluhung), Jurnal Teknik POMITS Vol. 2, No. 12013.

5. Wisnawa, T.S., Pribadi, T.W., dan Baihaqi, I., Analisis Risiko Terjadinya Kerusakan Kapal Pada Proses Penurunan Dengan Metode Air bag, Jurnal Teknik ITS Vol. 6, No.12017.

6. Al-Fian, M. F., Riantini, R., dan Subekti, A., Identifikasi Bahaya Proses Launching Kapal Menggunakan Sistem Marine Air bag Ship Pada Slipway Area Galangan Kapal PT Daya Radar Utama Unit Lamongan, Proceeding $1^{\text {st }}$ Proceeding Conference on Safety Engineering and Its Apllication Vol. 1 Book 22 September 2017.

7. Ariany, Z., Analisa Perhitungan Ballast Pada Peluncuran Menyamping (Side Launching) Kapal Sungai 200 GT Di PT $D K B$ (Persero) Cabang Semarang, Gema Teknologi Vol. 19 No. 4 Periode Oktober 2017 - April 2018.

8. Volenyuk, L.S. and Rashkovskyi, A.S., Ship stability analysis during launching from longitudinal sloping slipway by pneumatic air bags, Journal International Shipbuilding Progress, Vol. 64, no 1-2, p.41-50, 2017.

9. Fitriadhy, A., and Malek, A.M.A., Computational Fluid dynamics Analysis of a Ship's Side Launcing In Restricted Water, Journal of Mechanical Engineering and Sciencies Vol. 11, Issue 4, p.2993-3003, December 2017.

10. Rudan S., J. Urem and Zaninovic, A., Comparison of Ship Launching Evaluation methods, XX Symposium SORTA, 2012. 
11. Sitepu, G., Hamzah dan Firu, L.O.A.R., Kajian Penggunaan Fasilitas Dok Sistem Air bags Di PT DOK dan PERKAPALAN KODJA BAHARI Galangan II, Jakarta, Jurnal Riset dan Teknologi Kelautan Vol. 10, Nomor 2, Juli - Desember 2012.

12. Putra, I.D., Suwasono, B., dan Munazid, A., Penggunaan Rolling Air bag Slipway Pada Peluncuran Memanjang Periode I, Jurnal Sain dan Teknologi Vol. 9, No. 1 Februari 2011.
13. Tinandri, R.Q., Wahidin, A., dan Imron, A., Analisis Desain Layout Air bags Pada Peluncuran kapal Tanker 17500 LTDW Di PT Daya Radar Utama Unit Lamongan, Conference on Design and Manufacture and Its Aplication Vol. 1, No. 12017. 